\title{
Factors Influencing Pregnancy Rate and Late Embryonic Loss in Dairy Cattle
}

\author{
G Gábor ${ }^{1}$, F Tóth ${ }^{1}$, L Ózsvári ${ }^{2}$, Zs Abonyi-Tóth ${ }^{2}$ and RG Sasser ${ }^{3}$ \\ ${ }^{1}$ Research Institute for Animal Breeding and Nutrition, Herceghalom; ${ }^{2}$ Faculty of Veterinary Sciences, SZIE, Budapest, Hungary; ${ }^{3}$ Biotracking \\ LLC, Moscow, ID, USA
}

\section{Contents}

This trial was conducted on three Hungarian dairy farms between March 2003 and April 2004. The aims of this study were to examine the effect of milk production and milk contents, the day after calving (DAC) and the sire for the pregnancy rate (PR) and late embryonic loss (LEL) in dairies. Five thousand three hundred and eighty insemination was carried out in this period. Pregnancies $(n=1969)$ were detected by BioPryn ${ }^{\text {TM }}$ test from 3919 blood samples between 30-36 days post insemination (PI). Retention of pregnancy was determined by rectal palpation on Day 60. LEL has been determined by the optical density (OD) of blood samples/ cutoff ratio and the serum progesterone $(\mathrm{P} 4)$ concentration 30 36 days PI. According to serum progesterone concentration the authors predicted a presumed or possible embryonic loss or maintenance of the pregnancy. The efficiency of the artificial inseminations (AI) was significantly lower 60 days within postpartum. Significant positive correlation was found between the result of early and late PR and DAC and the milk protein/fat ratio. Significant negative correlation was detected between the early and late PR the milk protein and fat content. A later stage (60 days PI) of pregnancy the milk production has a negative effect for retaining of pregnancy. More data would be necessary to state that sires can influence the reproduction ability of their progenies. This is a really important issue, because the AI bulls have a great impact on the herds and the one-way selection may cause decreased fertility on breed level as well.

\section{Introduction}

Numerous epidemiological studies have suggested that environmental, individual cow and management factors influence reproductive efficiency and, particularly, first service conception rate post-partum (Buckley et al. 2003; Lopez-Gatius et al. 2003). Conception rate to first service is the combined consequence of fertilization, early embryonic, late embryonic and fetal development, and each of these steps in establishing pregnancy may be affected. Some of the reports suggest that, at least in intensively managed high-yielding cows, the fall in fertility may be due to a higher increment of both early (Sartori et al. 2000) and late (Vasconcelos et al. 1997) embryonic loss. Loss of pregnancy after early diagnosis is a factor in decreased reproductive efficiency. The factors for embryonic death in Boyd's (1965) opinion can be divided into two main classes: genetics factors (breed, family, inbreeding and blood groups) and environmental factors (nutrition, age, infections, hormonal imbalance and uterine environment). According to Santos et al. (2004) there are some other factors that can associated with pregnancy loss: the oocyte quality and persistent follicles, duration of pro-estrus and subsequent luteal phase, progesterone and uterine environment, pregnancy recognition and corpus luteum (CL) maintenance, heat stress, insemination protocols, effect of resynchronization, body condition score, cyclic status, milk yield, diseases, dietary ingredients and sire effect. Sreenan et al. (2001) calculated that fertilization rates of $90 \%$ and calving rates of $55 \%$ are normal for heifers and moderate yielding dairy cows, indicating an overall embryonic and fetal mortality rate of about $40 \%$. In recent studies, $7-33 \%$ of pregnancies in lactating dairy cows were lost between 28 and 98 days of gestation (Smith and Stevenson 1995; Inskeep 2002; Silke et al. 2002; Nation et al. 2003). Dailey et al. (2002) postulated that most loss of pregnancy occurs prior to day 45 of gestation.

A combination of oestrous observation, progesterone and pregnancy-specific protein b (PSPB) assays (Humblot 2001) and/or ultrasonography is necessary to identify late embryonic/fetal loss. According to Grimard et al. (2006) a study of the variation factors that may affect late embryonic/fetal loss could identify specific sources of variation of late embryonic mortality.

The aims of this study were to examine the effect of the (i) milk production (including the protein and fat content); (ii) the day after calving; and (iii) the sire for the pregnancy rate and late embryonic loss (LEL) in dairies.

\section{Materials and Methods}

This trial was conducted on three Hungarian dairy farms between March 2003 and April 2004. Five thousand three hundred and eighty insemination was carried out in this period. Pregnancies $(n=1969)$ were detected from 3919 blood samples between 30-36 days post insemination (PI) by BioPryn ${ }^{\mathrm{TM}}$. Re-check of the pregnancy and determination of embryonic loss was carried out by rectal palpation.

\section{Animals}

Crossbred (R2-R4) Holstein-Friesian cows aged 212.9 years (mean $4 \pm 1.78$ years) were bred within the experimental period. Cows calved 1-10 times (mean $2.3 \pm 1.55$ ) and number of service was $1-14$ (mean $2.46 \pm 1.78)$ respectively. Mean annual milk production of the three herds for ranged from 7800 to $9500 \mathrm{~kg}$ per cow in this period. The cows were milked two times daily.

\section{Pregnancy and LEL detection}

BioPryn $^{\text {TM }}$ test was used for the early pregnancy detection (30-36 days PI) (Gábor et al. 2004; Tóth et al. 2004a). Retention of pregnancy was determined by 
rectal palpation on Day 60 [day of artificial inseminations $(\mathrm{AI})=0$ ]. Low serum PSPB level served as a sign of the LEL (Tóth et al. 2004b). According to serum P4 concentration (measured in affected pregnant cows), cows were assigned to three categories: high $(>4 \mathrm{ng} / \mathrm{ml})$, medium $(2-4 \mathrm{ng} / \mathrm{ml})$ and low $(<2 \mathrm{ng} / \mathrm{ml})$ serum progesterone. The authors predicted a presumed (low) or possible (medium) embryonic loss or maintenance of the pregnancy (high).

\section{Examination of sire effect}

Data of sires with minimum 11 progenies were selected for further analysis. Two categories were formed from the bulls. Sires with positive impact (SPI) for the reproduction (mean day of progeny's insemination $>60$ and < 130 days post-partum, LEL \% < 12\%), and sires with negative impact (SNI) for the reproduction (mean day of progeny's insemination $>145$ days post-partum, LEL \% > $15 \%$ ).

\section{Data collection}

Milking data of the observed period were obtained from the Hungarian National Dairy Data Base. All reproduction data were collected from our own developed data base in our ELISA lab.

\section{Statistical analysis}

The dependent variables investigated (early and late PR and embryonic loss) were binary data $(0,1)$. The statistical procedure implemented was logistic regression (variables were early and rectal pregnancy rates, serum P4 concentration and daily mean milk production/ recorded monthly/, mean milk protein and fat $\mathrm{kg}$ and days after calving)

\section{Results}

\section{Pregnancy and embryonic loss data}

Both conception (CR; pregnancy data at 30-36 days PI) and pregnancy rates (pregnancy data at 60 days PI) were higher than the mean pregnancy results (Table 1) of the Holstein-Friesian herds in Hungary (2003: 29.1\%; 2004: 28.8\%). The distribution and efficiency of the predicted LEL is shown in Table 2. Both pregnancy and embryonic loss rates differed among the farms (PR: farm A: $32.8 \%$, farm B: $43.8 \%$, farm C: $36.1 \%$; LEL rate: farm I: $18.3 \%$, farm II: $14 \%$, farm III: $15.6 \%$ ).

Table 1. Pregnancy and LEL data of Farm A, B, C

\begin{tabular}{lrr}
\hline & No. & $\%$ \\
\hline AI & 5380 & \\
Pregnant (30-36 days PI) & 1969 & 36.6 \\
Pregnant (60 days PI) & 1649 & 30.7 \\
LEL (30-60) & 320 & 16.3 \\
Predicted true LEL (30-60) & 79 & 24.7 \\
\hline
\end{tabular}

LEL, late embryonic loss; AI, artificial inseminations; PI, post insemination.
Table 2. Distribution of the predicted embryonic loss based on serum progesterone level

\begin{tabular}{lccc}
\hline $\begin{array}{l}\text { Serum P4 } \\
\text { concentration }\end{array}$ & $\begin{array}{c}\text { Number of } \\
\text { predicted LEL }\end{array}$ & $\begin{array}{c}\text { Number of } \\
\text { determined LEL }\end{array}$ & $\begin{array}{c}\text { Efficiency of } \\
\text { diagnosis }\end{array}$ \\
\hline$<2 \mathrm{ng} / \mathrm{ml}$ & 38 & 26 & 68.4 \\
$2-4 \mathrm{ng} / \mathrm{ml}$ & 80 & 39 & 48.7 \\
$>4 \mathrm{ng} / \mathrm{ml}$ & 76 & 28 & $63.1^{\mathrm{a}}$ \\
\hline
\end{tabular}

LEL, late embryonic loss.

${ }^{a}$ Efficiency $\%$ is calculated on the number of pregnant remained cows

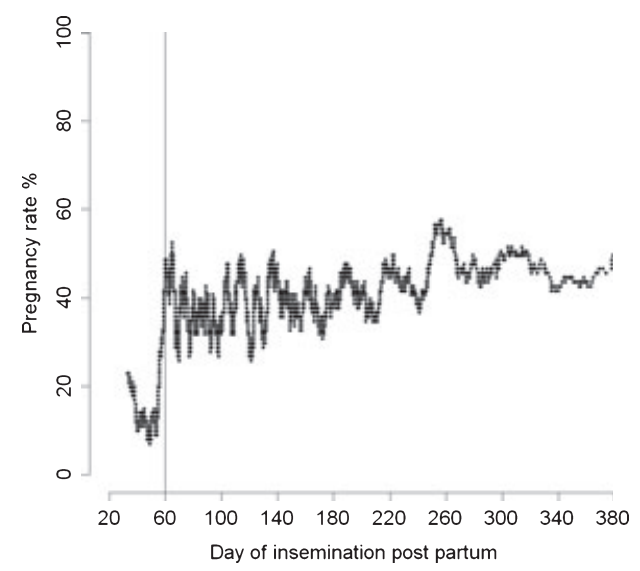

Fig. 1. Effect of day after calving for the pregnancy rate

\section{Effect of DAC for the CR and LEL}

The efficiency of the AI (Fig. 1) was significantly lower 60 days within post-partum $(\mathrm{p}<0.001)$, that's why these data were not used later in the statistical analysis. The number of the successful AI were higher after 300 days post-partum (PR: $45.5 \% ; p=0.014$ ).

Significant positive correlation was found between the result of early (30-36 days PI) and late (60 day PI) pregnancy results and the days after calving ( $\mathrm{p}<0.0001 ;$ Fig. 2). Significant negative correlation was found between the milk protein $\mathrm{kg}$ ( $\mathrm{p}<0.05$; Fig. 2); the milk fat $\mathrm{kg}(\mathrm{p}<0.0001)$ and the early and late pregnancy rate (Fig. 3). Significant positive correlation was detected between the early and late pregnancy rate and the milk protein $/$ milk fat ratio $(\mathrm{p}<0.05$; Fig. 3). A later stage (60 days PI) of pregnancy the milk production has a negative effect for retaining of pregnancy $(p=0.0018$; Fig. 4$)$. The LEL has been determined by the OD/cutoff ratio ( $p<0.0001$; Fig. 5) and the serum progesterone concentration $(\mathrm{p}<0.0001$; Fig. 5).

Beside the selection criteria some differences were detected between the sires (with positive and negative effect for the reproduction parameters) as shown in Table 3. Mean number of open cows, mean milk production and mean number of AI of open cows is higher in SNI group.

\section{Discussion}

It was observed several times that the recommended minimum of 50 days between calving and first service 
Fig. 2. Prediction of the early pregnancy rate based on the breeding day after calving or the milk protein content by the logistic model
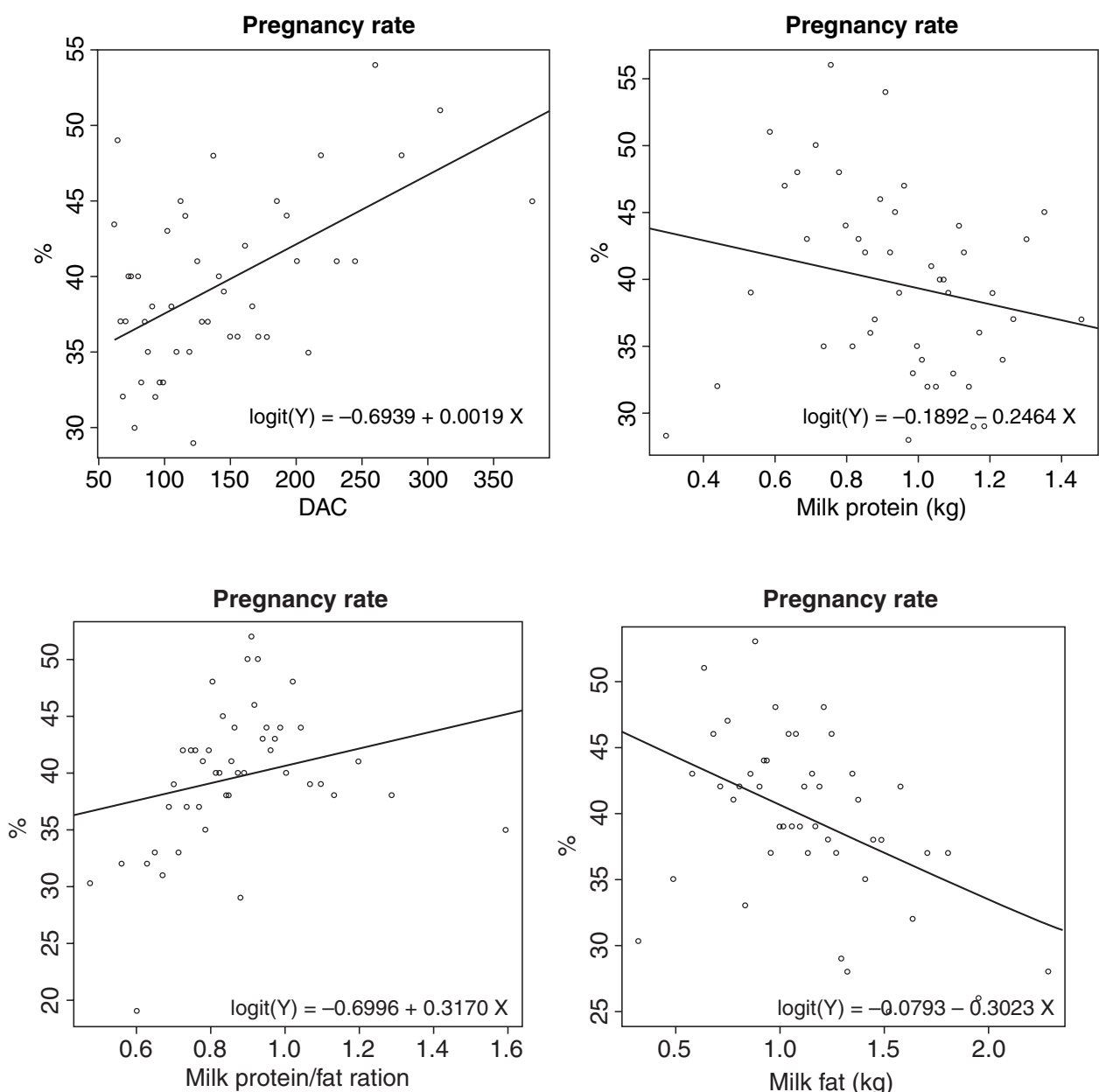

Fig. 3. Relationship between the milk protein/fat ratio or milk fat content and the early pregnancy rate

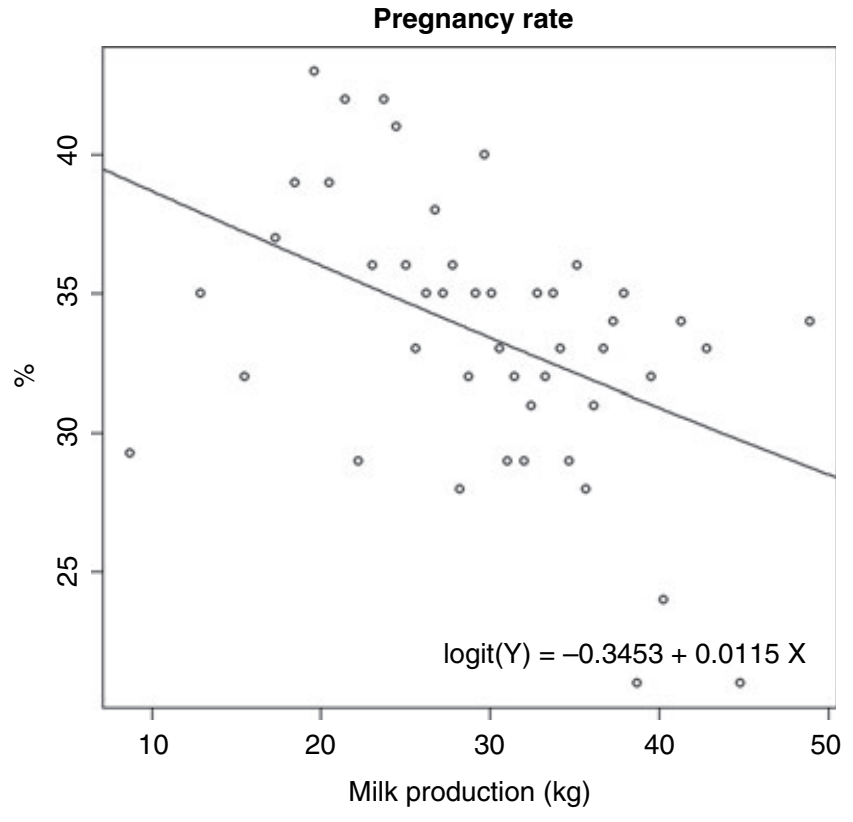

Fig. 4. Correlation between the milk production and the 60 days pregnancy rate

allow the completion of uterine involution. Additional delay before first AI for high yielding cows might have enhanced reproductive efficiency (Grimard et al. 2006).
Espinasse et al. (1998) reported that fertility was lower when AI was earlier than 50 days post-partum and particularly so before 30 days post-partum and conception rate increased as post-partum interval became longer. Some authors suggested that first service conception rate increased after 90 days post-partum as reported previously (Espinasse et al. 1998; Seegers et al. 2001). According Westwood et al. (2002) higher production of FCM during early lactation was associated with a longer interval from calving to first ovulation and with a reduced likelihood of expression of estrus and successful pregnancy by day 150 .

In our examinations close relationship was found between the DAC and early PR and it looks reasonable because the time duration since the parturition does not allow successful early breeding and the increased milk production has a negative impact for the fertility. Pregnancy data of almost 5400 cows (Fig. 1) demonstrates the importance of the voluntary waiting period.

In our experiments no significant negative correlation was found between the milk production and the early PR (30-36 days) over 60 days post-partum, but a well characterized trend-line could be fitted for the data. Several results and hypothesis were published in this topic, but the most of the authors examined the pregnancy at a later stage than 30-36 days PI. Hodel et al. (1995) found antagonistic genetic relationships of 0.6 and 0.7 between (female) fertility and milk production. In several examinations (Moate and Harris 1983; 


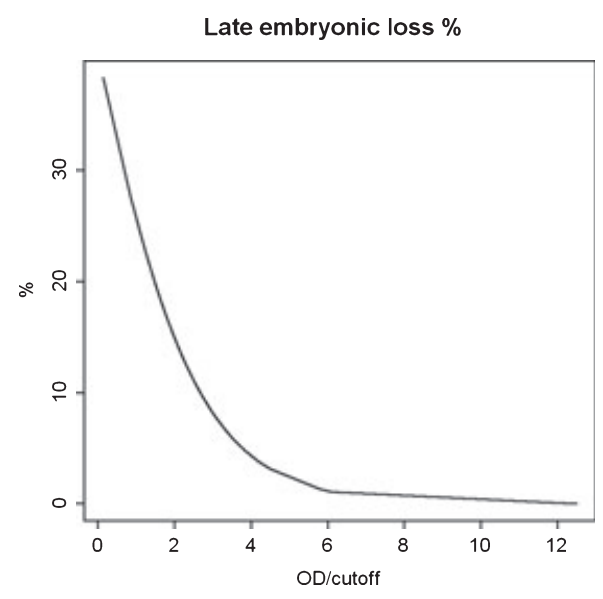

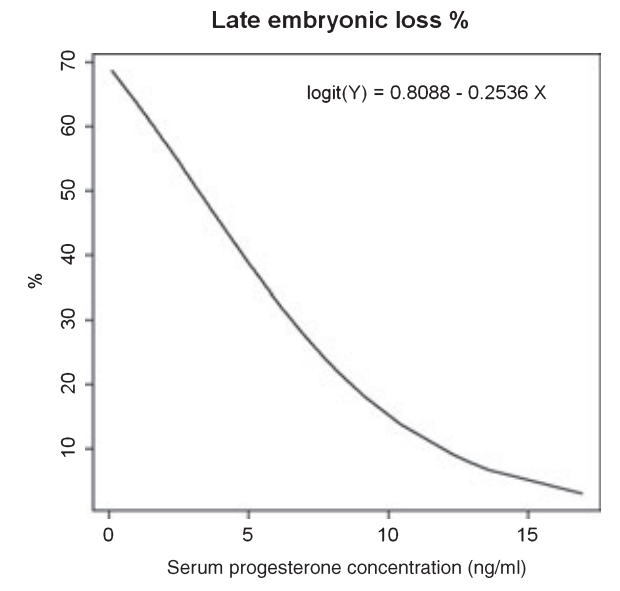

Fig. 5. Correlation between the $\mathrm{OD} /$ cutoff ratio or serum $\mathrm{P} 4$ concentration and LEL

\begin{tabular}{|c|c|c|}
\hline & $\begin{array}{l}\text { Sires with positive } \\
\text { impact }(\mathrm{n}=7)\end{array}$ & $\begin{array}{l}\text { Sires with negative } \\
\text { impact }(\mathrm{n}=17)\end{array}$ \\
\hline Mean number of progenies & 22.6 & 25.5 \\
\hline Mean number of pregnant cow & 20.6 & 19.9 \\
\hline Mean number of open cow & 2.3 & 5.6 \\
\hline Mean embryonic loss of the cows & 7.7 & 22.8 \\
\hline Mean milk of progenies & 30.4 & 30.8 \\
\hline Mean milk of the pregnant cows & 30.6 & 30.4 \\
\hline Mean milk of the open cows & 25.5 & 32.1 \\
\hline Mean day of insemination after calving & 118.3 & 162.3 \\
\hline Mean day of insemination after calving of pregnant cows & 117.5 & 167.0 \\
\hline Mean day of insemination after calving of open cows & 129.5 & 145.9 \\
\hline Mean number of AI of the examined pregnancy & 1.5 & 2.0 \\
\hline Mean number of AI of the examined pregnancy in pregnant cows & 2.2 & 3.1 \\
\hline Mean number of $\mathrm{AI}$ of the examined pregnancy in open cows & 2.1 & 2.7 \\
\hline
\end{tabular}

Table 3. Sire effect for pregnancy rate and the LEL

LEL, late embryonic loss; AI, artificial inseminations.

Fulkerson 1984; Buckley et al. 2003) positive correlation or no correlation was found (Villa-Godoy et al. 1988; Raheja et al. 1989), but the most of the authors stated negative correlation (Hoekstra et al. 1994; Beam and Butler 1999; Darwash et al. 1999; Royal et al. 2000) between the milk production and fertility. Buckley et al. (2003) demonstrated that the rapidly increased milk production has negative effect for the PR followed the first AI because of the physiological stress. High feed intake increases liver blood flow and the metabolism of progesterone and estradiol in dairy cattle (Sangsritavong et al. 2002). In this trial significant negative correlation was found between the milk production and PR 60 days PI. This negative significant correlation (Fig. 4) probably means that increased milk production between 30 and 60 days PI does not influence auspiciously the retaining of pregnancy. The milk production itself probably does not have the same effect that's why no correlation was found between the early (30-36 days) PR and the LEL. Grimard et al. (2006) stated that the milk production effect might be the consequence of the combined effects of genetic (negative genetic correlation between milk production and conception rate) and nutritional effects (lower energy balance and longer post-partum period of negative energy balance in high producing cows). In the opinion of Pryce and Veerkamp (2001) the genetic background is the responsible for the decreased fertility. Similar results were published by Hoekstra et al. (1994): the 56 days non return rate
(NRR) and the fertility of the first service have been decreased in parallel by the increasing of the HolsteinFriesian blood ratio.

According to Heuer et al. (1992) both the fat/protein ratio and the percentage fat (de Vries and Veerkamp 2000) are good predictors of fertility. In this trial significant negative correlation was found (Figs 2 and 3) between the early (30-36 days PI) and late (60 days PI) pregnancy rates and milk protein $\mathrm{kg}(\mathrm{p}<0.05)$ and the milk fat $\mathrm{kg}(\mathrm{p}<0.0001)$.

The significant positive correlation between the early and late pregnancy rates and the milk protein/milk fat ratio ( $\mathrm{p}=0.013$; Fig. 3 ) might be caused by lower milk production, because it usually associates with higher milk-protein content. Distl et al. (1989) showed that ketonaemia in high-yielding cows is associated with a depressed milk-protein content. Opsomer et al. (2000) showed that cows suffering ketonaemia and cows with depressed milk-protein content were at significantly higher risk to suffer from inactive ovaries after calving.

Milk-protein content and protein/fat ratio is often used as an indicator of energy balance. Because the milk-protein concentration is influenced by the level of energy supply to the cows (Coulon and Remond 1991), milk-protein concentration might predict the time to first insemination and be useful to track down fertility problems. Fulkerson et al. (2001) showed that cows with the lowest milk-protein content suffered the most severe and prolonged negative energy balance (NEBAL), 
compared with cows with milk-protein content more than $3 \%$.

Determination of LEL by the OD/cutoff ratio probably means that the most of the cases low PSPB serum concentration means a decreasing tendency - and it probably caused by the dying of embryo (Fig. 5).

The negative significant correlation between the serum P4 concentration and LEL is well known because the progesterone is responsible for maintaining the pregnancy and any decrease of it can cause embryonic loss. Franco et al. (1987) showed that cows suffering pregnancy loss from gestation day 24 to 63 had lower milk progesterone concentration on days 21 and 24 after insemination. Other authors (Lopez-Gatius et al. 2002) agreed with these findings: in cows undergoing pregnancy loss the CL may show depressed progesterone secretion during the late embryonic and early fetal period.

More data would be necessary to state that sires can influence the reproduction ability of their progenies. Coulter and Foote (1979) published that the larger testis size of the bulls correlated with younger age at puberty and higher conception rate in related females. Starbuck et al. (2004) stated that one of the most-frequently used sires had a lower pregnancy retention rate, and other AI sires had lower pregnancy rates 9 weeks PI than the natural-service sire. Although pregnancy rates were comparable among the AI sires, pregnancy retention varied. Lopez-Gatius et al. (2002) reported that the particular bull providing the inseminate may also be a risk factor for pregnancy loss, cows bred to one of six sires had a 3.4 times greater risk of pregnancy loss between 38 and 90 days of gestation than those bred to the other five sires. Humblot and Denis (1986) found an effect of the sire on the distribution of return to estrus after service, but they did not find evidence of sire effects on late embryonic death. In this study the most of the examined parameters (not statistically) differed among the data of the two groups of sires (sires with negative and/or positive impact for their daughter's fertility; Table 3). But Hodel et al. (1995) grouped of bulls according to their breeding value estimates for male fertility and found significant effects of service bull on the fertility. Although in this study we could not state the sire effect for the LEL, further investigations are necessary to examine this area, because there are several observations and data what support that idea. This is a really important issue, because all of AI bulls have a great impact on the herds and the one-way selection of bulls (milk production) may cause decreased fertility on breed level as well.

\section{References}

Beam SW, Butler WR, 1999: Energy balance effects on follicular development and first ovulation in post-partum cows. J Reprod Fertil 54(Suppl.), 411-424.

Boyd H, 1965: Embryonic death in cattle, sheep and pigs. Vet Bull Weybridge 35, 251-266.

Buckley F, O’Sullivan K, Mee JF, Evans RD, Dillon P, 2003: Relationships among milk yield, body condition, cow weight, and reproduction in spring-calved Holstein-Friesians. J Dairy Sci 86, 2308-2319.
Coulon JB, Remond B, 1991: Variations in milk output and milk protein content in response to the level of energy supply to the dairy cow: a review. Livest Prod Sci 29, $31-47$.

Coulter GH, Foote RH, 1979: Bovine testicular measurements as indicators of reproductive performance and their relationship to productive traits in cattle: a review. Theriogenology 11, 297-311.

Dailey RA, Inskeep EK, Lewis PL, 2002: Pregnancy failures in cattle: a perspective on embryo loss. In: Proceedings of the XVIIIth International Conference on Reproduction of Farm Animals. Slovakia, pp. 1-8.

Darwash AO, Lamming GE, Woolliams JA, 1999: The potential for identifying heritable endocrine parameters associated with fertility in post-partum dairy cows. J Anim Sci 68, 333-347.

Distl O, Wurm A, Glibotic G, Brem G, Krauslich H, 1989: Analysis of relationships between veterinary recorded production diseases and milk production in dairy cows. Livest Prod Sci 23, 67-78.

Espinasse R, Disenhaus C, Philippot JM, 1998: D'elai de mise a reproduction, niveau de production et fertilit chez la vache laiti'ere. Rencontres Recherche Ruminants 5, 79-82.

Franco OJ, Drost M, Thatcher MJ, Shille VM, Thatcher WW, 1987: Fetal survival in the cow after pregnancy diagnosis by palpation per rectum. Theriogenology 27, 631-644.

Fulkerson WJ, 1984: Reproduction in dairy cattle: effect of age, cow condition, production level, calving-to-first-service interval and the 'male'. Anim Reprod Sci 7, 305-314.

Fulkerson WJ, Wilkins J, Dobos RC, Hough GM, Goddard ME, Davidson T, 2001: Reproductive performance in Holstein-Friesian cows in relation to genetic merit and level of feeding when grazing pasture. J Anim Sci 73, 397-406.

Gábor G, Tóth F, Szász F, 2004: Influence of synchronized ovulation and pre-synchronization on pregnancy rates used timed AI in lactating dairy cows. In: Abstract Book of the 15th International Congress on Animal Reproduction, vol 2., Porto Seguro, Brazil, pp. 338.

Grimard B, Freret S, Chevallier A, Pinto A, Ponsart C, Humblot P, 2006: Genetic and environmental factors influencing first service conception rate and late embryonic/foetal mortality in low fertility dairy herds. Anim Reprod Sci 91, 31-44.

Heuer C, Schukken YH, Dobbelaar P, 1992: Postpartum body condition score and results from the first test day milk as predictors of disease, fertility, yield, and culling in commercial dairy herds. J Dairy Sci 82, 295-304.

Hodel F, Moll J, Kuenzi N, 1995: Analysis of fertility in Swiss Simmental cattle - genetic and environmental effects on female fertility. Livest Prod Sci 41, 95-103.

Hoekstra J, Van der Lugt AW, Van der Werf JHJ, Ouweltjes W, 1994: Genetic and phenotypic parameters for milk production and fertility traits in upgraded dairy cattle. Livest Prod Sci 40, 225-232.

Humblot P, 2001: Use of pregnancy specific proteins and progesterone assays to monitor pregnancy and determine the timing, frequencies and source of embryonic mortality in ruminants. Theriogenology 56, 1417-1433.

Humblot P, Denis JB, 1986: Sire effects on cow fertility and late embryonic mortality in the Montbeliard breed. Livest Prod Sci 14, 139-148.

Inskeep EK, 2002: Factors that affect embryonic survival in the cow: application of technology to improve calf crop. In: Fields MJ, Sand RS, Yelich JY (eds), Factors Affecting Calf Crop: Biotechnology of Reproduction. CRC Press, Boca Raton, FL, pp. 255-275.

Lopez-Gatius F, Santolaria P, Janiz J, Ruttlant J, Lopez-Bejar M, 2002: Factors affecting pregnancy loss from gestation 
day 38 to 90 in lactating dairy cows from a single herd. Theriogenology 57, 1251-1261.

Lopez-Gatius F, Yaniz J, Madriles-Helm D, 2003: Effect of body condition score and score change on the reproductive performance of dairy cows: a meta-analysis. Theriogenology 59, 801-812.

Moate PJ, Harris DJ, 1983: A Survey to Determine the Influence of Cow Condition Score, Calving to Service Interval, Age and Milk Yield on Cow Fertility. Dairy Production Report. Dairy Research Institute, Ellinbank, Australia, pp. 106-108.

Nation DP, Malmo J, Davis GM, 2003: Accuracy of bovine pregnancy detection using transrectal ultrasonography at 28 to 35 days after insemination. Aust Vet J 81, 63-65.

Opsomer G, Grohn YT, Hertl J, Coryn M, Deluyker H, de Kruif A, 2000: Risk factors for post-partum ovarian dysfunction in high producing dairy cows in Belgium: a field study. Theriogenology 53, 841-857.

Pryce JE, Veerkamp RF, 2001: The incorporation of fertility indices in genetic improvement programmes. In: Fertility in High Producing Dairy Cow, British Society of Animal Science Occasional Publication No. 26, Galway, Ireland, pp. 237-249.

Raheja KL, Burnside EB, Schaeffer LR, 1989: Relationship between fertility and production in Holstein dairy cattle in different lactations. J Dairy Sci 72, 2670-2678.

Royal MD, Darwash AO, Flint APE, Webb R, Woolliams JA, Lamming GE, 2000: Declining fertility in dairy cattle: changes in traditional and endocrine parameters of fertility. Anim Sci 70, 487-501.

Sangsritavong S, Combs DK, Sartoru R, Armentano LE, Wiltbank MC, 2002: High feed intake increases liver blood flow and metabolism of progesterone and estradiol-17beta in dairy cattle. J Dairy Sci 85, 2831-2842.

Santos JEP, Thatcher WW, Chebel RC, Cerri RLA, Galvao KN, 2004: The effect of embryonic death in cattle on the efficacy of oestrous synchronization programs. Anim Reprod Sci 82-83, 513-535.

Sartori R, Sartor-Bergfelt R, Mertens SA, Guenther JN, Parrish JJ, Wiltbank MC, 2000: Early embryonic development during summer in lactating dairy cows and nulliparous heifers. Biol Reprod Suppl 62, 155.

Seegers H, Coulon R, Beaudeau F, Fouchet M, Quillet JM 2001: Etude descriptive et identification de facteurs de variation de diff 'erentes cat'egories de retours apr'es ins'emination artificielle en troupeaux laitiers. Rencontres Recherche Ruminants 8, 357-360.
Silke V, Diskin MG, Kenny DA, Boland MP, Dillon P, Meec JF, Sreenan JM, 2002: Extent, pattern and factors associated with late embryonic loss in dairy cows. Anim Reprod Sci 71, 1-12.

Smith MW, Stevenson JS, 1995: Fate of the dominant follicle, embryonal survival, and pregnancy rates in dairy cattle treated with prostaglandin F2 alpha and progestins in the absence or presence of a functional corpus luteum. J Anim Sci 73, 3743-3751.

Sreenan JM, Diskin MG, Morris DG, 2001: Embryo survival rate in cattle: a major limitation to the achievement of high fertility. In: Anim Sci, Vol. 1, Fertility in the high producing dairy car. Occasional Publication No.26, Galway, Ireland pp. $93-104$.

Starbuck MJ, Dailey RA, Inskeep EK, 2004: Factors affecting retention of early pregnancy in dairy cattle. Anim Reprod Sci 84, 27-39.

Tóth F, Gábor G, Szász F, Huang F, Sasser RG, 2004a: Early pregnancy detection by BIOPRYN ${ }^{\mathbf{T M}}$ ELISA test in dairy cattle. In: Abstract Book of the 15 th International Congress on Animal Reproduction, Vol. 1. Porto Seguro, Brazil, pp. 73.

Tóth F, Gábor G, Huang F, Sasser RG, 2004b: Prediction of the embryonic loss by pregnancy-specific protein B (PSPB) ELISA test in dairy cattle. Biol Reprod Spec Issue 71, 152.

Vasconcelos JLM, Silcox RW, Lacerda JA, Pursley JR, Wiltbank MC, 1997: Pregnancy rate, pregnancy loss, and response to heat stress after AI at 2 different times from ovulation in dairy cows. Biol Reprod 56 (Suppl. 1), 140 (abstract).

Villa-Godoy A, Hughs TL, Emery RS, Chapin LT, Fogwell RL, 1988: Associations between energy balance and luteal function in lactating dairy cows. J Dairy Sci 71, 1063.

de Vries MJ, Veerkamp RF, 2000: Energy balance in dairy cattle in relation to milk production variables and fertility. $\mathbf{J}$ Dairy Sci 83, 62-69.

Westwood CT, Lean IJ, Garvin JK, 2002: Factors influencing fertility of Holstein dairy cows: a multivariate description. J Dairy Sci 85, 3225-3237.

Submitted: 20.12 .2006

Author's address (for correspondence): Dr G. Gabor, Research Institute for Animal Breeding and Nutrition, Gesztenyes Str 1, Herceghalom, 2053, Hungary. E-mail: h12617gab@helka.iif.hu 